\title{
O Uso do Régua e Compasso no Estudo da Construção do Arco Capaz
}

\author{
Gabriel Fernando Costa da Silva* \\ Universidade Federal do Pará, Faculdade de Matemática \\ 68600000, Bragança - PA \\ E-mails: gabriel_ferna@hotmail.com.br \\ Edson Jorge de Matos \\ Universidade Federal do Pará, Faculdade de Matemática \\ 68600000, Bragança - PA \\ E-mail: edsonjm@ufpa.br
}

\section{RESUMO}

Neste trabalho apresentaremos o uso da geometria dinâmica e interativa, através do software Régua e Compasso, que é um software livre que permite usar os conhecimentos da Geometria Plana e Analítica para realizar construções geométricas e animações, através dos recursos que simulam a régua e compasso reais, que são oferecidos pelo software. Dessa maneira contribuindo para a construção do pensamento sistemático, haja vista que problemas envolvendo construções geométricas nem sempre são entendidos e/ou resolvidos facilmente pelos alunos, considerada ainda de grande complexidade pelos mesmos. Em virtude disso usaremos o software para proporcionar uma visualização mais ampla do conteúdo aprendido em sala de aula, além de relacionar o conhecimento teórico prático, saindo das esferas tradicionais com o uso da lousa e do livro didático.

A escolha de usar o software livre e não o proprietário é que não teríamos custos elevados de instalação em várias máquinas, além do mesmo poder ser usado, copiado, modificado e distribuído livremente, para que outros possam usufruir do aplicativo. Outro motivo foi que com o software livre evitamos a pirataria e o ensino de práticas ilegais, além do fato de que, qualquer falha no programa é uma oportunidade para colaborar com o programador enviando informações dos erros, pois os softwares pertencem a uma comunidade em que todos colaboram para melhorar o programa. Dessa forma todos se beneficiam e compartilham o conhecimento promovido pela comunidade o que são pontos positivos ao usar o software livre [4].

Segundo [2] "A informática na educação deve ser visto não apenas como um direito, mais como parte de um projeto de democratização de acessos a tecnologias desenvolvidas por essa mesma sociedade. Deve ser justificada pela alfabetização tecnológica e direito a acesso". Porém como cita os Parâmetros Curriculares Nacionais [1] "o bom uso que se possa fazer do computador na sala de aula também depende da escolha de softwares, em função dos objetivos que se pretende atingir". Outro aspecto que deve ser salientado é que "ao adotar o software livre no contexto educativo, contribuímos para a democratização do saber, diminuindo o grande fosso da exclusão digital" [3].

$\mathrm{Na}$ utilização do software livre "Régua e Compasso" podem ser observados a precisão dos desenhos geométricos criados no aplicativo com o uso de suas ferramentas, sendo dessa maneira um grande facilitador para o professor nas construções de teoremas e particularidades de disciplinas como Construções Geométricas, Geometria Plana, Geometria Analítica, entre outras do Curso de Matemática, haja vista que fazer os desenhos na lousa é um tanto complicado para o professor (requer habilidade), dificultando o ensino aprendizagem, a visualização do aluno na construção dos desenhos e um melhor entendimento da disciplina.

Fundamentando-se nas ideais apresentadas anteriormente, propomos adotar no primeiro momento a apresentação do programa aos alunos do curso de Licenciatura em Matemática, explorando suas ferramentas e funcionalidade. Depois foram feitas as resoluções de problemas e teoremas da disciplina construções geométricas, destacando a construção do arco capaz. Neste exemplo, verifica-se numericamente através do software que o ângulo $A \hat{P} B$ permanece constante para quaisquer pontos $P$ no arco de centro $O$ e extremidades $\overline{A B}$ como mostra a figura (1). Também pudemos observar que o ângulo $A \hat{O} B$ é duas vezes maior que o ângulo $A \widehat{P} B$. 
A construção teve os seguintes passos: i) traçar um seguimento $\overline{A B}$ qualquer, ii) traçar a mediatriz deste seguimento, iii) transportar o ângulo $\theta=30^{\circ}$ onde $\left(0<\theta \leq 90^{\circ}\right)$ para $\mathrm{o}$ seguimento $\overline{A B}$, iv) traçar a semi reta $A X$ e uma perpendicular a essa semi reta v) marcar a interseção da perpendicular com a mediatriz (ponto $O$ ), vi) traçar o círculo centrado em $O$ e raio $\overline{O A}$ formando o arco capaz de centro $O$ e extremidades $\overline{A B}$ como mostra a figura abaixo:

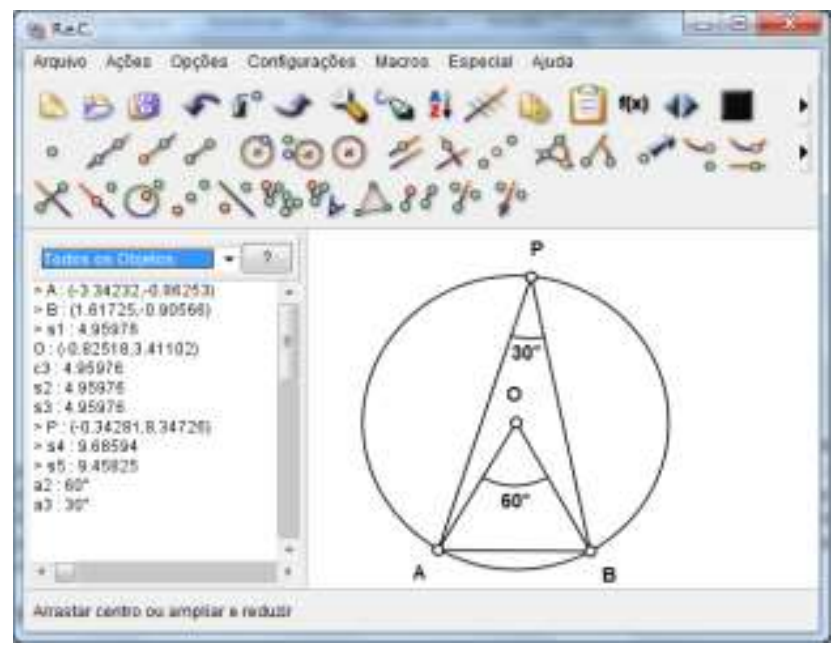

Figura 1 - Arco Capaz do ângulo de $30^{\circ}$

Partindo das ideias de Zulatto [7] e Silva [6] o software de Geometria Dinâmica permite ao aluno formular suas conjecturas e a partir daí, buscar suas próprias conclusões, que se torna possível devido os recursos do software, com a ferramenta "arrastar", que possibilita manipular e explorar diferentes casos e particularidades da figura na tela do computador. Nesse sentido, o ensino aprendizagem passa a ser mais significativo para o aluno.

Palavras-chave: Software Livre, Régua e Compasso, Arco Capaz.

\section{Referências}

[1] S. E. F. Brasil; "Parâmetros Curriculares Nacionais: Matemática". Brasília: MEC/SEF, 1998.

[2] M. C. Borba, M. G. Penteado; "Informática e Educação Matemática”. 3. ed. Belo Horizonte: Autêntica, 2003.

[3] S. Duarte; "Implementando Projetos Educativos Inovadores com Software Livre". Revista Espírito Livre, S.I.: n 48, pp. 47 - 52, Out. 2012.

[4] I. Fernandez; "Por que usar software livre na educação?”. Revista Espirito Livre, S.I.: n 48, pp. 35 - 36, Out. 2012.

[5] Régua e Compasso - Download e ajuda disponível em http://www.rene-grothmann.de/.

[6] J.J. Silva; "O Software Régua e Compasso como Recurso Metodológico para o Ensino de Geometria Dinâmica". Dissertação de Mestrado, Centro de Ciências e Tecnologia, Universidade Estadual da Paraíba, 2011.

[7] R. B. A. Zulatto; "Professores de Matemática que Utilizam Software de Geometria Dinâmica: suas características e perspectivas". Dissertação de Mestrado, Instituto de Geociência e Ciências Exatas, Universidade Estadual Paulista, Rio Claro, 2002. 